\title{
The use of information sources and online databases for writing theses by students of selected studies
}

\author{
Urszula Malaga-Toboła ${ }^{1, *}$, Stawomir Kocira ${ }^{2}$, and Agnieszka Szparaga ${ }^{3}$ \\ ${ }^{1}$ Department of Production Organization, Logistics and Applied Computer Science, University \\ of Agriculture in Krakow, Poland \\ ${ }^{2}$ University of Life Sciences in Lublin, Department of Machinery Exploitation and Management \\ of Production Processes, 20650 Lublin, Poland \\ ${ }^{3}$ Koszalin University of Technology, Department of Agrobiotechnology, 75-620 Koszalin, Poland
}

\begin{abstract}
The paper presents the results of research on the use of electronic publications for writing theses by first and second degree students of two engineering and technical studies: agriculture and forestry technology, and management and production engineering. 53 first-degree and 175 second-degree students were included in the study. It was found that both first and second degree students use electronic publications on a par with printed ones when writing their theses. First-degree students preferred Google Scholar, while second-degree students preferred Polish scientific publishers. The choice of both the Google Scholar database and the pages of Polish scientific publications resulted from the possibility to search for papers in Polish, which was the main language of publication chosen by both groups of students.
\end{abstract}

\section{Introduction}

In recent decades, the dynamic development of information technologies greatly affected the process of media communication [1]. The development has had a decisive impact on interactions within communication communities and on intercultural communication [2]. Changes in communication and researching information also apply to researchers and students $[4,3]$. This process could not be avoided by the academia. In science, the process of data digitization was developed and covered, e.g. scientific journals and popular science magazines. When publishing articles in an electronic version, many of these magazines made them available to a wide audience in the open access (OA) model. Along with such widespread dissemination of research results, there was a need for publishers to make decisions regarding their readers, especially concerning the language, in which the works were published. Therefore, a number of magazines have started to publish articles in English to expand the audience.

*Corresponding author: umalagatobola@gmail.com 
Nowadays, publications in this language should not be a problem for students and researchers because the vast majority speak the language. In the course of studies, students of various fields are assigned a number of project, interim or final papers, as well as dissertations. Completing the assignment requires reading and using a lot of information available in a variety of sources. Students of engineering and technical studies working on their dissertations are the group that particularly uses the latest data. This is due to the dynamic development of this area of science. Therefore, the process of selecting information sources for engineering and master's dissertations is an interesting and important issue from the point of view of the strategy for the development of digitalization of knowledge resources.

The aim of this work is to answer the question which of the sources of information are most often used in dissertations by students of management and production engineering as well as agriculture and forestry technology (agricultural engineering), and why.

\section{Materials}

The material is the result of research carried out using a diagnostic survey among seniors of the full-time, first-degree studies (the last semester) and seniors of the second-time, firstdegree studies (the last semester). The respondents were students of management and production engineering (162 people) and agriculture and forestry technology (66 people) from two universities: University of Life Sciences in Lublin and University of Agriculture in Krakow.

The students completed an online survey containing single and multiple choice questions. The survey consisted of three main parts: the first was a personal data sheet, the second included information regarding computer ownership and internet access, and the third, major part concerned the sources used for writing dissertations, and criteria for searching publications. Students also answered the question regarding the reason behind using the selected literature sources.

\section{Results \& Discussion}

\subsection{Literature sources}

The survey was completed by 228 students, including 116 men and 112 women. Firstdegree studies were represented by 53 students, and second-degree studies, by 175 . All respondents owned a computer and had internet access at their place of residence during their studies. In addition to using information found online in their dissertations, firstdegree students readily resorted to traditional forms of publication (books, printed scientific journals) (Fig. 1). Research bulletin, which is a less popular form of publishing works. Students of agriculture and forestry technology used more sources, as compared to the students of management and production engineering. This may indicate difficulties in finding the right literature for the discussed topics. 


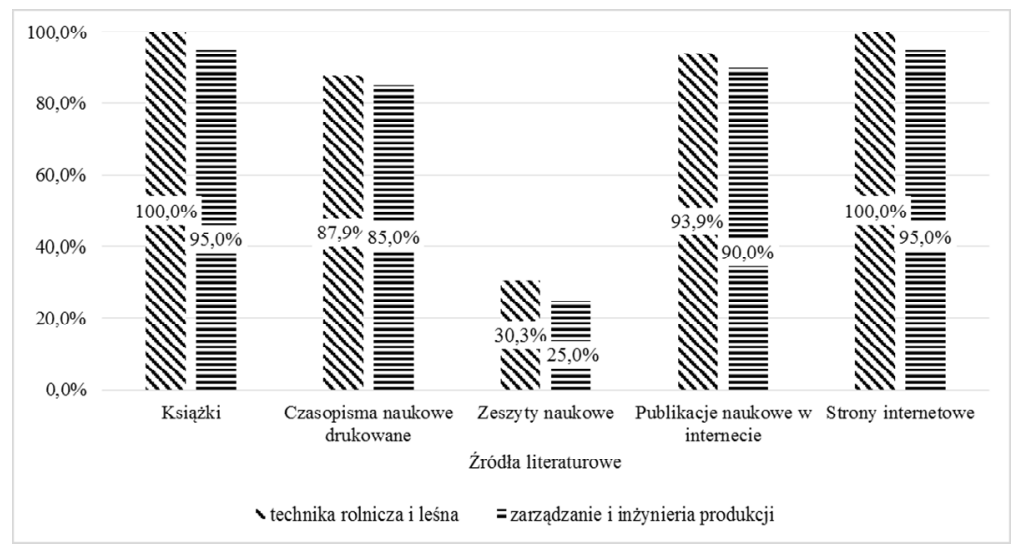

Fig. 1. Literature sources used by first-degree students for writing their dissertations.

Similarly as in the case of first-degree students, also second-degree students of agriculture and forestry technology used more sources than the students of management and production engineering (Fig. 2). In the case of agriculture and forestry technology students, there is little interest in printed scientific journals, as compared to students of management and production engineering as well as of first-degree studies in both fields. Students of both fields of study treat traditional forms of resources on an equal footing with electronic ones. Research conducted by Milewska [5] on a group of 81 doctoral students from the Lódzkie Province shows that all respondents use digital publications in their scientific work. Research by Kocira et al. [6] show that both students and lecturers use publications in a digital form more often than those in print.

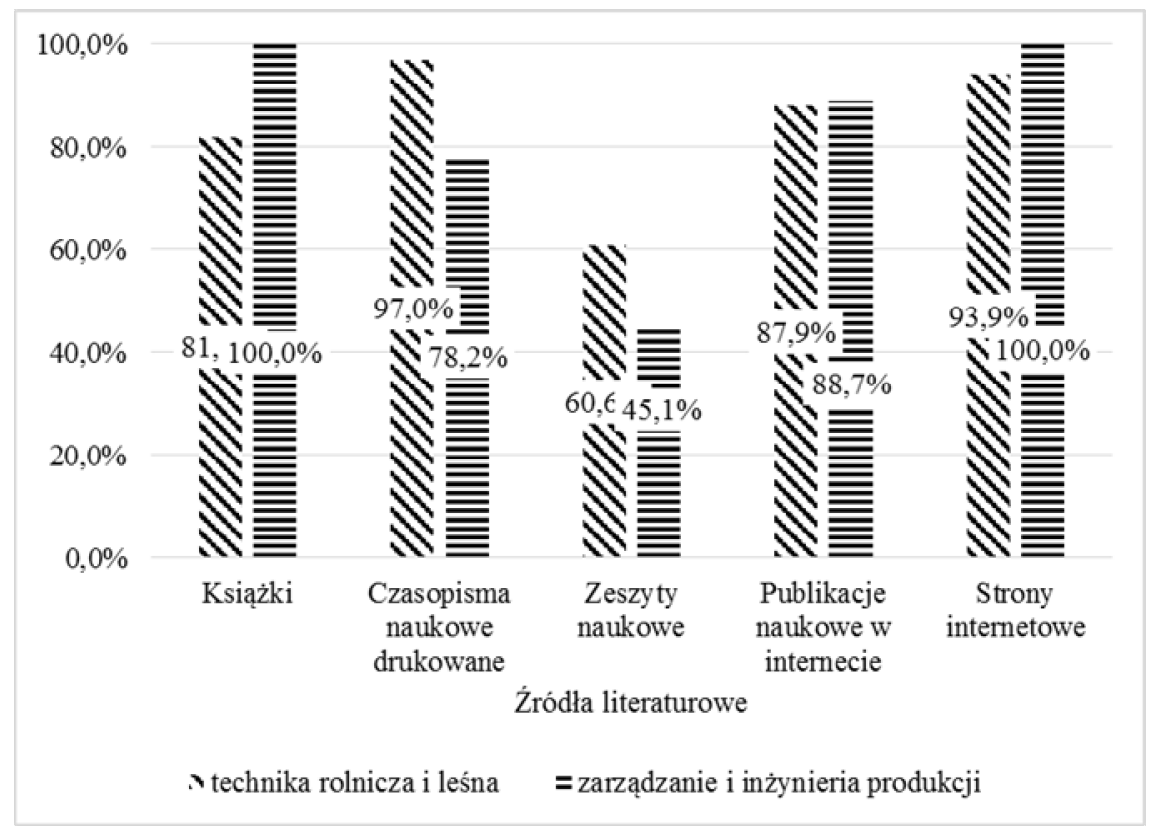

Fig. 2. Literature sources used by second-degree students for writing their dissertations. 


\subsection{Digital publications}

When looking for the literature needed to write their dissertations, first-degree students of both fields of study most often used Google scholar. The Web of Science and Scopus databases were the least used,

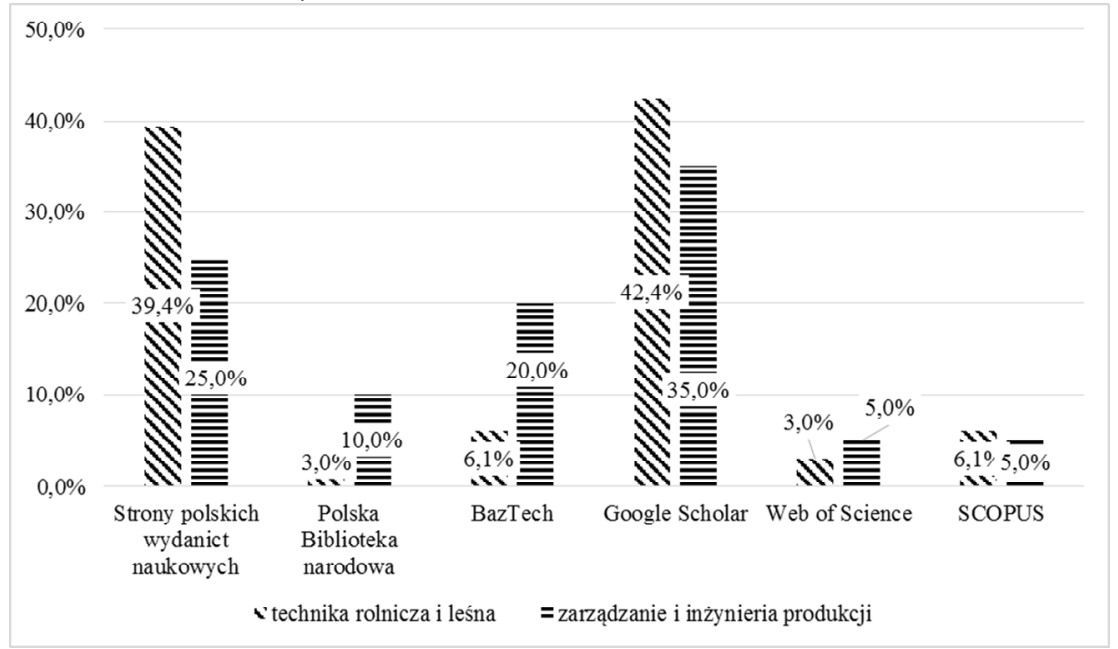

Fig. 3. The sources of scientific publications made available in digital form most often chosen by first-degree students.

Students of both fields of study most often used publications made available directly on the publishing house's website and in the Google Scholar database (Fig. 4). The Polish National Library (Polska Biblioteka Narodowa) and Web of Science and Scopus databases were the least popular among students. In the case of the last two databases, low popularity results from the limited access to them in the place of residence, and the necessity of English to use them. Also, Kocira et al. [6] showed that academic teachers most often used the websites of Polish scientific publishers as well as the Web of Science and Scopus databases.

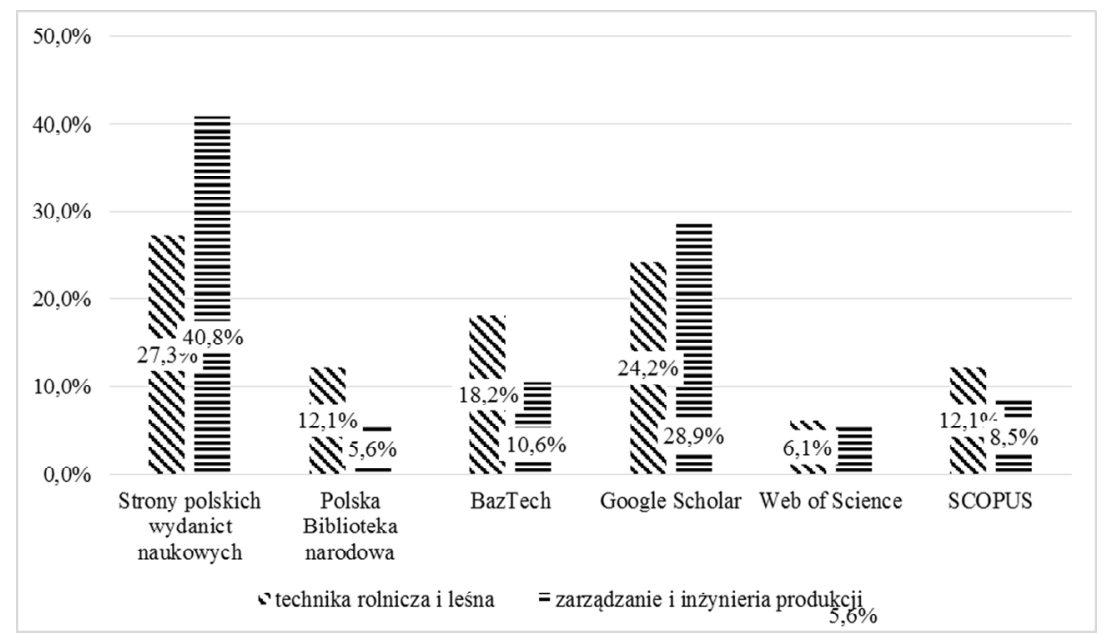

Figure 4. Sources of scientific publications most often chosen by second-degree students, made available in a digital form. 


\subsection{Language of the publications}

Students of both fields of study preferred publications in Polish, or in both Polish and English. Only $6.1 \%$ of agriculture and forestry technology students, and $5 \%$ of production management and engineering students preferred a language other than Polish or English. The data obtained shows that these were foreign students.

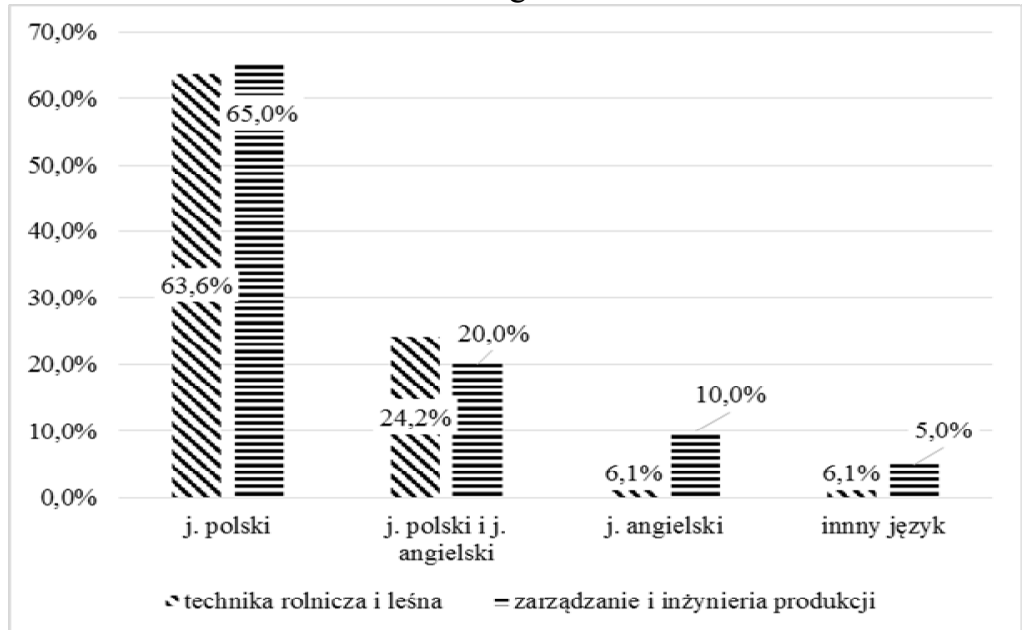

Figure 5. Selection of the language of scientific publications by the surveyed seconddegree students.

Over 54\% respondent students of agriculture and forestry technology choose Polishlanguage publications, and over 33\% choose Polish- or English-language ones (Fig. 6). Management and production engineering students definitely preferred Polish-language publications. A small percentage of students of both fields of study use publications in a language other than Polish or English. Such a low interest in publications in other languages indicates the selection of publications according to the knowledge of languages (Polish - mother tongue, English - most often learned), and the largest number of publications available in these two languages in the above mentioned sources.

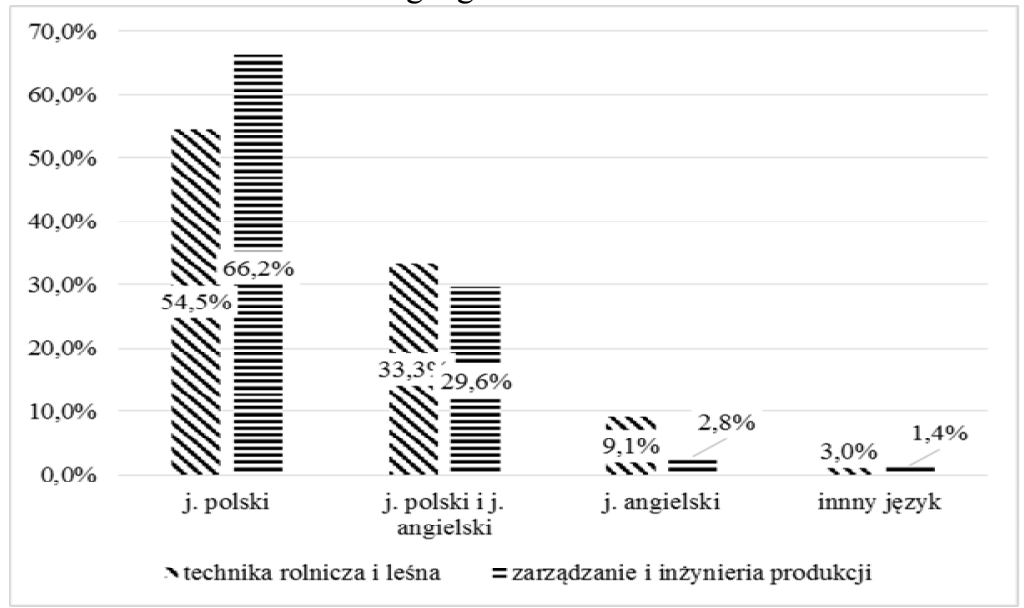

Figure 6. Selection of the language of scientific publications by the surveyed seconddegree students. 


\section{Conclusions}

The research of a group of first- and second-degree students allowed to determine that both first and second degree students use electronic publications on a par with printed ones when writing their theses. In the case of using digital versions of articles, first-degree students preferred Google Scholar, while second-degree students preferred Polish scientific publishers. The choice of both the Google Scholar database and the pages of Polish scientific publications resulted from the possibility to search for papers in Polish, which was the main language of publication chosen by both groups of students.

\section{References}

1. E. Lorencowicz, M. Koszel, S. Kocira, J. Uziak, Agricultural Engineering, 21, 69-76, (2017).

2. M. Bugajski, Język w komunikowaniu, Wydawnictwo Naukowe PWN (2007).

3. M. Cupiał, A. Szelag-Sikora, J. Sikora, J. Rorat, M. Niemiec. Working Papers, 20, (2017),

4. M. Cupiał, A. Szelagg-Sikora, M. Kuboń. The use of ICT in the didactic process of students' education. Proceedings of the International Scientific Conference. Volume V, (2018).

5. P. Milewska, Publikacje elektroniczne w pracy młodego naukowca. Analiza wyników badań ankietowych przeprowadzonych na terenie województwa tódzkiego. In Czyżewska (Ed.), Publikacje elektroniczne w rozwoju nauki polskiej (33-44), Wydawnictwo Wyższej Szkoły Ekonomicznej w Białymstoku, (2012)

6. S. Kocira, M. Kuboń, U. Malaga-Toboła, D. Kwaśniewski. Academic Teachers' preferences in Selecting Scientific Databases. Proceedings of the International Scientific Conference, Volume V (2019). 